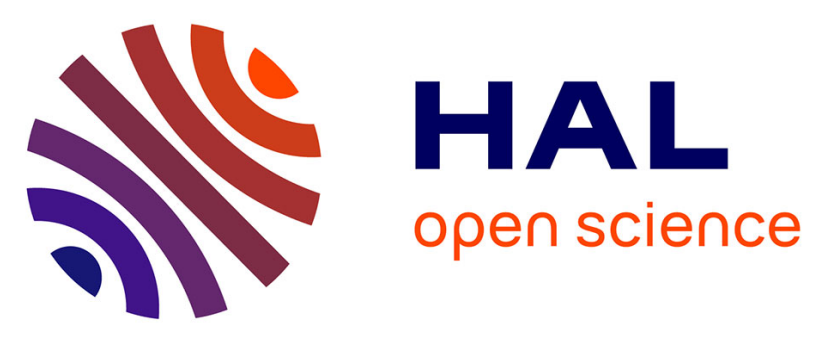

\title{
Metformin improves postprandial glucose homeostasis in rainbow trout fed dietary carbohydrates: a link with the induction of hepatic lipogenic capacities?
}

Stéphane Panserat, Sandrine Skiba-Cassy, Iban Seiliez, Marine Lansard, Elisabeth Plagnes Juan, Christiane Vachot, Pierre Aguirre, Laurence L. Larroquet, G. Chavernac, Françoise Médale, et al.

\section{To cite this version:}

Stéphane Panserat, Sandrine Skiba-Cassy, Iban Seiliez, Marine Lansard, Elisabeth Plagnes Juan, et al.. Metformin improves postprandial glucose homeostasis in rainbow trout fed dietary carbohydrates: a link with the induction of hepatic lipogenic capacities?. AJP - Regulatory, Integrative and Comparative Physiology, 2009, 297 (3), pp.R707-R715. 10.1152/ajpregu.00120.2009 . hal-02668247

\section{HAL Id: hal-02668247 https://hal.inrae.fr/hal-02668247}

Submitted on 31 May 2020

HAL is a multi-disciplinary open access archive for the deposit and dissemination of scientific research documents, whether they are published or not. The documents may come from teaching and research institutions in France or abroad, or from public or private research centers.
L'archive ouverte pluridisciplinaire HAL, est destinée au dépôt et à la diffusion de documents scientifiques de niveau recherche, publiés ou non, émanant des établissements d'enseignement et de recherche français ou étrangers, des laboratoires publics ou privés. 


\section{S. Panserat, S. Skiba-Cassy, I. Seiliez, M. Lansard, E. Plagnes-Juan, C. Vachot, P. Aguirre, L. Larroquet, G. Chavernac, F. Medale, G. Corraze, S. Kaushik and T.}

W. Moon

Am J Physiol Regulatory Integrative Comp Physiol 297:707-715, 2009. First published Jun 24, 2009; doi:10.1152/ajpregu.00120.2009

You might find this additional information useful...

This article cites 53 articles, 22 of which you can access free at:

http://ajpregu.physiology.org/cgi/content/full/297/3/R707\#BIBL

This article has been cited by 1 other HighWire hosted article:

Glucose homeostasis is impaired by a paradoxical interaction between metformin and insulin in carnivorous rainbow trout

S. Polakof, S. Skiba-Cassy and S. Panserat

Am J Physiol Regulatory Integrative Comp Physiol, December 1, 2009; 297 (6): R1769-R1776.

[Abstract] [Full Text] [PDF]

Updated information and services including high-resolution figures, can be found at:

http://ajpregu.physiology.org/cgi/content/full/297/3/R707

Additional material and information about American Journal of Physiology - Regulatory, Integrative and Comparative Physiology can be found at:

http://www.the-aps.org/publications/ajpregu

This information is current as of September 7, 2010 .

The American Journal of Physiology - Regulatory, Integrative and Comparative Physiology publishes original investigations that illuminate normal or abnormal regulation and integration of physiological mechanisms at all levels of biological organization, ranging from molecules to humans, including clinical investigations. It is published 12 times a year (monthly) by the American

Physiological Society, 9650 Rockville Pike, Bethesda MD 20814-3991. Copyright @ 2009 by the American Physiological Society. ISSN: 0363-6119, ESSN: 1522-1490. Visit our website at http://www.the-aps.org/. 


\title{
Metformin improves postprandial glucose homeostasis in rainbow trout fed
}

\section{dietary carbohydrates: a link with the induction of hepatic lipogenic} capacities?

\author{
S. Panserat, ${ }^{1,2,3}$ S. Skiba-Cassy, ${ }^{1,2,3}$ I. Seiliez, ${ }^{1,2,3}$ M. Lansard, ${ }^{1,2,3}$ E. Plagnes-Juan, ${ }^{1,2,3}$ C. Vachot, ${ }^{1,2,3}$ \\ P. Aguirre, ${ }^{1,2,3}$ L. Larroquet, ${ }^{1,2,3}$ G. Chavernac, ${ }^{4}$ F. Medale, ${ }^{1,2,3}$ G. Corraze, ${ }^{1,2,3}$ S. Kaushik, $, 1,3$ \\ and T. W. Moon ${ }^{5}$ \\ ${ }^{1}$ Institut National de la Recherche Agronomique, Joint Research Unit 1067 Nutrition Aquaculture et Génomique, \\ Saint-Pée-sur-Nivelle; ${ }^{2}$ Institut Français de Recherche pour l'Exploitation de la Mer, Joint Research Unit 1067 Nutrition \\ Aquaculture et Génomique, Plouzané; ${ }^{3}$ Université Bordeaux 1, Joint Research Unit 1067 Nutrition Aquaculture et \\ Génomique, Talence; ${ }^{4}$ Department of Toxicology, Merck Santé, Lyon, France; and ${ }^{5}$ Department of Biology and Centre for \\ Advanced Research in Environmental Genomics, University of Ottawa, Ottawa, Ontario, Canada
}

Submitted 23 February 2009; accepted in final form 17 June 2009

\begin{abstract}
Panserat S, Skiba-Cassy S, Seiliez I, Lansard M, Plagnes-Juan E, Vachot C, Aguirre P, Larroquet L, Chavernac G, Medale F, Corraze G, Kaushik S, Moon TW. Metformin improves postprandial glucose homeostasis in rainbow trout fed dietary carbohydrates: a link with the induction of hepatic lipogenic capacities? Am J Physiol Regul Integr Comp Physiol 297: R707-R715, 2009. First published June 24, 2009; doi:10.1152/ajpregu.00120.2009.—Carnivorous fish are poor users of dietary carbohydrates and are considered to be glucose intolerant. In this context, we have tested, for the first time in rainbow trout, metformin, a common anti-diabetic drug, known to modify muscle and liver metabolism and to control hyperglycemia in mammals. In the present study, juvenile trout were fed with very high levels of carbohydrates (30\% of the diet) for this species during 10 days followed by feeding with pellets supplemented with metformin $(0.25 \%$ of the diet) for three additional days. Dietary metformin led to a significant reduction in postprandial glycemia in trout, demonstrating unambiguously the hypoglycemic effect of this drug. No effect of metformin was detected on mRNA levels for glucose transporter type 4 (GLUT4), or enzymes involved in glycolysis, mitochondrial energy metabolism, or on glycogen level in the white muscle. Expected inhibition of hepatic gluconeogenic (glucose-6-phosphatase, fructose1,6-bisphosphatase, and phosphoenolpyruvate carboxykinase) mRNA levels was not found, showing instead paradoxically higher mRNA levels for these genes after drug treatment. Finally, metformin treatment was associated with higher mRNA levels and activities for lipogenic enzymes (fatty acid synthase and glucose-6-phosphate dehydrogenase). Overall, this study strongly supports that the induction of hepatic lipogenesis by dietary glucose may permit a more efficient control of postprandial glycemia in carnivorous fish fed with high carbohydrate diets.
\end{abstract}

glucose; anti-diabetic drug; muscle; liver; carnivorous fish

TELEOST FISH SUCH AS THE RAINBOw trout (Oncorhynchus mykiss) are characterized by a limited efficiency to use even digestible carbohydrates (55) and are thus considered as "glucose intolerant" $(21,34)$. Oral or intravenous administration of glucose or a carbohydrate-rich diet results in a persistent hyperglycaemia in various fish species, including rainbow trout $(4,8,14$, $15,17,31,37)$, and is also associated with elevated insulin levels, very much like in mammals $(8,17)$. Insulin receptors

Address for reprint requests and other correspondence: S. Panserat, INRA, UMR1067 Nutrition Aquaculture Génomique, Pôle d'hydrobiologie, CD918, F-64310 St-Pée-sur-Nivelle, France (e-mail: panserat@st-pee.inra.fr). are present in major insulin-responsive tissues, including white muscle, liver, and adipose tissues (19, 42, 43, 35). Upregulation of insulin binding and tyrosine kinase activities is observed after insulin treatment and carbohydrate-rich diets, respectively $(2,19,42,43)$. The persistent hyperglycemia in rainbow trout fed with carbohydrates despite the existence of insulin secretion and tissue receptors suggests an insulin resistance state comparable to that observed in humans with type II non-insulin-dependent diabetes mellitus.

Absorbed glucose is efficiently transported by enterocytes in the blood, as reflected by the induction of sodium-dependent glucose cotransporters in trout-fed carbohydrates (27). In rainbow trout, a system similar to that proposed in mammals involved in the detection of changes in circulating glucose levels by pancreatic $\beta$-cells and glucose-excited neurons in the hypothalamus and the brain stem appears to be functional and inducible $(48,49)$. Glucose uptake mediated by the facilitative insulin-regulated glucose transporter GLUT4 homolog in white muscle and fat tissues and by GLUT2 in liver are observed in trout $(6,9,10,30)$. At the metabolic level, most key enzymes involved in carbohydrate metabolism are described in fish (7). For some such as glucokinase (GCK; EC 2.7.1.2) (liver), phosphofructokinase (EC 2.7.1.11) (liver and muscle), and pyruvate kinase (PK; EC 2.7.1.40) (liver and muscle), their induction by dietary carbohydrates is similar to that described in mammalian systems $(16,38,41)$. However, data on other metabolic actors of glucose metabolism suggest the existence of an atypical regulation after carbohydrate intake by trout, including a lower capacity for glucose phosphorylation by hexokinases (HKs) in the muscle of fish than in mammalian species, which was further confirmed by the poor utilization of exogenous glucose as a glycogenic substrate in trout muscle $(23,26,55)$. In addition, carbohydrate-rich diets do not affect the activity or mRNA levels of key enzymes of trout hepatic gluconeogenesis, including glucose-6-phosphatase (G-6-Pase; EC 3.1.3.9), fructose-1,6-bisphosphatase (FBPase; EC 3.1.3.11) or phosphoenolpyruvate carboxykinase (PEPCK; EC 4.1.1.49) $(27,39,40,41)$ in contrast to mammals $(12,33$, 51). Such an impaired postprandial downregulation of insulinregulated gluconeogenic enzymes in rainbow trout fed with carbohydrates is similar to the insulin resistance observed in human patients with type II diabetes. We thus propose the hypothesis that dietary glucose intolerance in rainbow trout is 
mainly related to impaired transcriptional (down) regulation of hepatic gluconeogenic genes $(27,40,41,42)$.

Metformin (1,1-dimethylbiguanide hydrochloride) is an antidiabetic drug used extensively for the treatment of human type 2 diabetes improving glucose homeostasis without modification of insulin secretion (28). The major effect of metformin in mammals is an inhibition of gluconeogenesis by downregulating hepatic gluconeogenic mRNA levels through activation of AMP-activated protein kinase (AMPK) (53). Treatment with metformin was reported in two cyprinid species, the common carp (Cyprinus carpio) and the zebrafish (Danio rerio), both known to be glucose tolerant $(13,22)$. Our objective in this study was to analyze the effect of metformin in seemingly glucose-intolerant rainbow trout by feeding them with or without carbohydrates for 10 days followed by a metformin treatment for an additional 3 days. We analyzed mRNA levels for the gluconeogenic enzymes G-6-Pase, FBPase and mitochondrial (m) PEPCK 2, 6, and $24 \mathrm{~h}$ after the last feeding. Because metformin has other extragluconeogenic molecular targets in mammalian liver and muscle $(20,28)$, we also studied the mRNA levels of the muscle GLUT4, three glycolytic enzymes [low Michaelis constant HK (EC 2.7.1.1), GCK, PK], two mitochondrial enzymes [3-hydroxyacyl-CoA dehydrogenase (HOAD; EC 1.1.1.35); citrate synthase (CS; EC 2.3.3.1)], and two lipogenic enzymes [glucose-6-phosphate dehydrogenase (G-6-PDH; EC 1.1.1.49); fatty acid synthase (FAS; EC 2.3.1.85)].

\section{METHODS}

Fish and diets. A 2-wk growth study was undertaken with groups of juvenile rainbow trout ( 15 fish/tank; initial body mass $90 \mathrm{~g}$ ) reared in our experimental fish farm (INRA, St.-Pee, France) at $18^{\circ} \mathrm{C}$ under an artificial photoperiod (light from 8:00 A.M. to 8:00 P.M.). Three isocaloric diets were formulated and manufactured in our experimental unit (see Table 1). The diet + Cho contained a high level of carbohydrate (30\% of gelatinized starch) and the diet - Cho was devoid of carbohydrate. A third diet + Cho+Met was supplemented with metformin (Merck, Paris, France) at a level of $0.25 \%$ in the diet [to give $50 \mathrm{mg}$ metformin $\cdot$ day $^{-1} \cdot \mathrm{kg} \mathrm{fish}^{-1}$, a common dose used in mammalian studies (28)]. Fish were hand-fed two times daily at $2 \%$ body weight for 10 days with the +Cho diet in four tanks or with the -Cho diet in two tanks. Following this 10-day period, the fish were fed for an additional 3 days with either + Cho or - Cho diets while two tanks of fish fed initially with + Cho were fed with the + Cho + Met diet.

Tissue and blood sampling. At the end of the trial, six fish per group (3/tank) were randomly sampled 2, 6, and $24 \mathrm{~h}$ after the meal to follow the postprandial phase. Trout were killed by a sharp blow to the head. Blood was removed from the caudal vein and centrifuged (3,000 $\mathrm{g}, 5 \mathrm{~min})$, and the recovered plasma was immediately frozen and kept at $-20^{\circ} \mathrm{C}$. Gut content of each fish was systematically checked to assert that the fish sampled had effectively consumed the diet. Liver and a sample of dorsoventral white muscle were immediately dissected, weighed, immediately frozen in liquid nitrogen, and kept at $-80^{\circ} \mathrm{C}$. The experiment was conducted following the Guidelines of the National Legislation on Animal Care of the French Ministry of Research (Decret no. 2001-464 of May 29, 2001) and was approved by the Ethics Committee of Institut National de la Recherche Agronomique (according to INRA No. 2002-36 of April 4, 2002).

Chemical composition of the diets. The experimental diets were analyzed using the following procedures: dry matter after drying at $105^{\circ} \mathrm{C}$ for $24 \mathrm{~h}$, starch by the glucoamylase glucose oxidase method (54), and gross energy using an adiabatic bomb calorimeter (IKA,
Table 1. Composition of diets

\begin{tabular}{lccc}
\hline \multicolumn{1}{c}{ Ingredients, \% } & - Cho & + Cho & + Cho+Met \\
\hline Fish meal $^{1}$ & 81 & 57 & 57 \\
Fish oil $^{2}$ & 8 & 10 & 10 \\
Gelatinized starch $^{3}$ & 0 & 30 & 30 \\
-Cellulose $^{4}$ & 8 & 0 & 0 \\
Binder $^{5}$ & 1 & 1 & 1 \\
Mineral $^{6}$ & 1 & 1 & 1 \\
Vitamins $^{7}$ & 1 & 1 & 1 \\
Metformin $^{8}$ & 0 & 0 & 0.25 \\
Analytical composition $^{\text {DM, \% }}$ & & & \\
Protein, \%DM $_{\text {Lipids, \%DM }}$ & 96.2 & 93.2 & 93.7 \\
Energy, kJ/g DM & 60.7 & 42.4 & 42.9 \\
Starch, \% DM & 15.2 & 13.0 & 12.8 \\
$\quad$ Ash, \% DM & 21.7 & 21.3 & 22.0 \\
\hline
\end{tabular}

DM, dry matter; -Cho, without carbohydrate; +Cho, with carbohydrate; + Cho+Met, with carbohydrate and metformin. ${ }^{1}$ Fish meal (Sopropèche, Boulogne-sur-Mer, France); ${ }^{2}$ Feedoil (North sea fish oil; Sopropèche, Boulogne-sur-Mer, France); ${ }^{3}$ Lestrem 62 (Roquette, France); ${ }^{4} \alpha$-celluose (SigmaAldrich); ${ }^{5}$ Alginate GF 150 (Louis François exploitation, Saint-Maur, France); ${ }^{6}$ Mineral mixture (g or mg/kg diet): $2.15 \mathrm{~g}$ calcium carbonate $(40 \% \mathrm{Ca}) ; 1.24 \mathrm{~g}$ magnesium oxide $(60 \% \mathrm{Mg}) ; 0.2 \mathrm{~g}$ ferric citrate; $0.4 \mathrm{mg}$ potassium iodide (75\% I); $0.4 \mathrm{~g}$ zinc sulfate $(36 \% \mathrm{Zn}) ; 0.3 \mathrm{~g}$ copper sulfate $(25 \% \mathrm{Cu}) ; 0.3 \mathrm{~g}$ manganese sulfate (33\% Mib); $5 \mathrm{~g}$ dibasic calcium phosphate (20\% Ca, $18 \%$ $\mathrm{P}) ; 2 \mathrm{mg}$ cobalt sulfate; $3 \mathrm{mg}$ sodium selenite $(30 \% \mathrm{Se}) ; 0.9 \mathrm{~g} \mathrm{KCl}$; and $0.4 \mathrm{~g}$ $\mathrm{NaCl}$ \{unité de préparation des aliments expérimentaux (UPAE), Jouy, Inra, France $\} ;{ }^{7}$ Vitamin mixture (IU or $\mathrm{mg} / \mathrm{kg}$ diet): $60 \mathrm{IU}$ DL- $\alpha$-tocopherol acetate; $5 \mathrm{mg}$ sodium menadione bisulfate; 15,000 IU retinyl acetate; 3,000 IU DL-cholecalciferol; $15 \mathrm{mg}$ thiamin; $30 \mathrm{mg}$ riboflavin; $15 \mathrm{mg}$ pyridoxine; 0.05

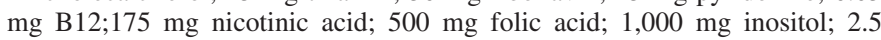
biotin; $50 \mathrm{mg}$ calcium panthotenate; 2,000 $\mathrm{mg}$ choline chloride (UPAE); ${ }^{8}$ metformin (Merck, Paris, France).

Heitersheim Gribheimer, Germany). Protein content $(N \times 6.25)$ was determined by the Kjeldahl method after acid digestion.

Plasma metabolites and glycogen content. Plasma glucose concentration was determined using the glucose oxidase method with a Beckman glucose analyzer (Beckman II). Plasma triglyceride levels were measured by a colorimetric enzyme assay using hepatic lipase (EC 3.1.1.3), glycerokinase (EC 2.7.1.30), glycerol-3-phosphate oxidase (EC 1.1.3.21), and peroxidase (EC 1.1.11) (PAP 150 kit; Biomérieux, Marcy-l'étoile, France). Plasma free fatty acid levels were measured by a colorimetric enzyme assay using acyl-CoA synthetase, acyl-CoA oxidase, and peroxidase (Wako Nefa C kit; Wako Chemicals, Neuss, Germany). Liver and muscle glycogen were determined according to Ref. 25.

Enzyme activities. Estimates of lipogenic FAS and G-6-PDH activities were undertaken according to Ref. 50. Glycolytic (HK and PK) enzyme activities were measured as described by Kirchner et al. (24). Enzyme activities are expressed per milligram of protein. Protein concentration was determined using a Bradford protein assay kit (Bio-Rad, München, Germany) with BSA as standard. All of the estimates for each individual were performed in duplicate.

$m R N A$ level analysis by real-time quantitative RT-PCR. Total RNA was extracted from rainbow trout liver and white muscle using TRIzol reagent (Invitrogen, Carlsbad, CA). Total RNA (1 $\mu \mathrm{g})$ was reverse transcribed into cDNA with the Superscript III RNAse H Reverse Transcriptase kit (Invitrogen) using oligo(dT) primers. mRNA levels were determined by real-time quantitative RT-PCR (q-PCR) using the iCycler iQ (Bio-Rad, Hercules, CA). Analyses were performed on 10 $\mu l$ of the diluted cDNA using the $\mathrm{iQ}^{\mathrm{TM}}$ SYBR Green Supermix (Bio-Rad), in a total PCR reaction volume of $25 \mu$ l, containing 200 $\mathrm{nM}$ of each primer. Primers were designed to overlap an intron if possible (Primer3 software) using known sequences in nucleotide databases (Table 2) as previously described (47). Relative quantifica- 
Table 2. Sequences of the primer pairs used for real-time quantitative PCR determination of the transcript level of several rainbow trout genes involved in glucose, lipid, and energy metabolism

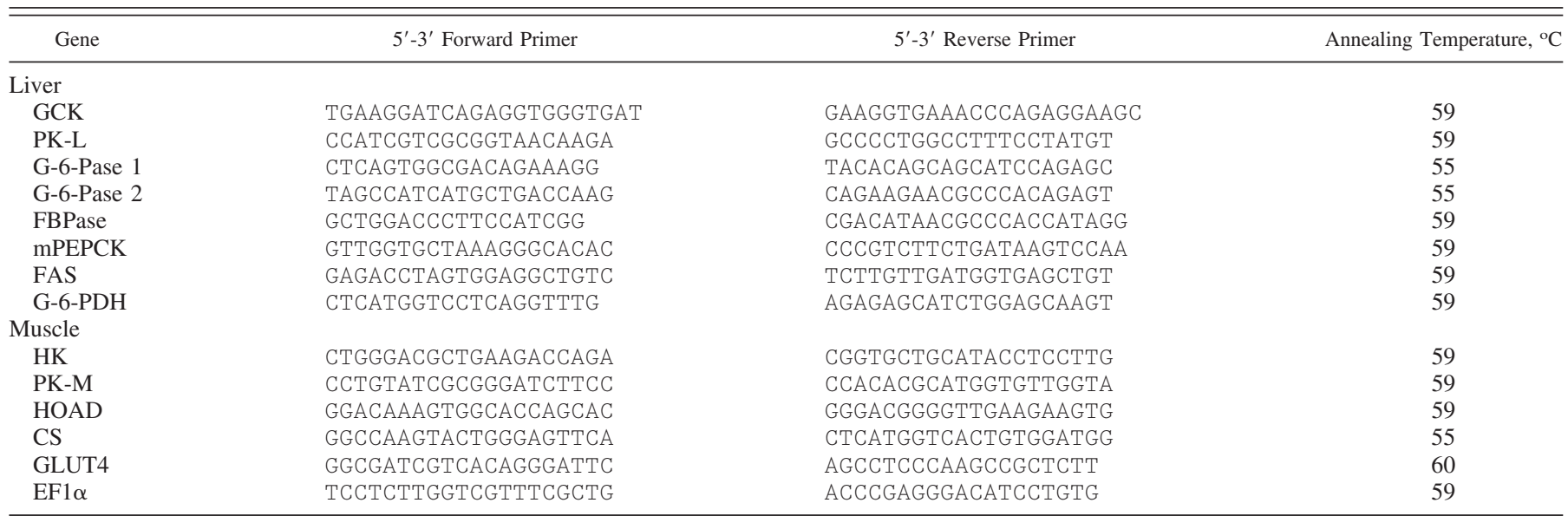

GenBank accession no. or sigenae accession nos. in parentheses: EF1 $\alpha$, elongation factor $1 \alpha$ (AF498320); GCK, glucokinase (AF135403); PK, pyruvate kinase, liver isoform (AF246146); mPEPCK, phosphoenolpyruvate carboxykinase, mitochondrial isoform (AF246149); G-6-Pase 1, glucose 6-phosphatase 1 (tcay0019b.d.18_3.1.s.om.8.1-1693); G-6-Pase 2, glucose 6-phosphatase 2 (AF120150); FBPase, fructose-1,6-bisphosphatase (AF333188); FAS, fatty acid synthase (tcab0001c.e.06_5.1.s.om.8); G-6-PDH, glucose-6-phosphate dehydrogenase (CA351434); HK, hexokinase (AY864082); PK-M, pyruvate kinase, muscle isoform (tcav0004c.c.07_3.1.om.4); HOAD, hydroxyacyl-CoA-dehydrogenase (tcad0001a.i.15_3.1.om.4); CS, citrate synthase (TC89195); GLUT4, glucose transporter type 4 (AF247395).

tion of the target gene transcript was done using efl $\alpha$ mRNA level as described previously (36), which was stably expressed in this experiment. Thermal cycling was initiated with incubation at $95^{\circ} \mathrm{C}$ for $90 \mathrm{~s}$ using hot-start iTaq DNA polymerase activation; 35 steps of PCR were performed, each one consisting of heating at $95^{\circ} \mathrm{C}$ for $20 \mathrm{~s}$ for denaturing, and at specific annealing and extension temperatures as noted on Table 2. Following the final PCR cycle, melting curves were systematically monitored $\left(55^{\circ} \mathrm{C}\right.$ temperature gradient at $0.5^{\circ} \mathrm{C} / \mathrm{s}$ from 55 to $94^{\circ} \mathrm{C}$ ) to ensure that only one fragment was amplified. Samples without reverse transcriptase and samples without RNA were run for each reaction as negative controls. For each sample, two RTs were performed, and for each RT two PCRs were done.

Data analysis. Data are presented as means \pm SD. Except for q-PCR data analysis, we analyzed the effect of the three different dietary treatments independently at each postprandial sampling time using a Kruskal-Wallis nonparametric test. Relative quantification of the target gene transcript with the $e f l \alpha$ reference gene transcript was made following the Pfaffl method with the Relative Expression Software tool (REST) $(45,46)$. This mathematical algorithm computes an expression ratio based on q-PCR efficiency and the crossing point deviation of the unknown sample vs. a control group: $\mathrm{R}=$

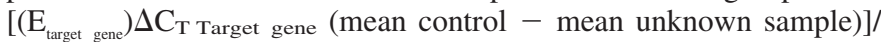
$\left[\left(\mathrm{E}_{\mathrm{EF} 1 \alpha}\right) \Delta \mathrm{C}_{\mathrm{T} E \mathrm{EF} 1 \alpha}\right.$ (mean control - mean unknown sample $\left.)\right]$ where $\mathrm{E}$ is PCR efficiency determined using a standard curve of cDNA serial dilutions (cDNA dilutions from $1 / 16$ up to $1 / 512$ ) and $\Delta C_{T}$ is the crossing point deviation of an unknown sample vs. a control. Statistical differences in mRNA levels between control and sample were evaluated as group means by randomization tests (46) using REST software; 2,000 random allocations were performed, and significant differences were considered at $P<0.05$. For the comparison between fish fed with and without carbohydrate, the control group is the carbohydrate-free group, whereas, for the comparison between fish treated with or without metformin, the control group is the metforminfree group.

\section{RESULTS}

Rainbow trout were killed 13 days after the dietary treatments (with or without carbohydrates), including the last 3 days with metformin for the drug-treated group. Data on postprandial plasma glucose, free fatty acids, and triglycerides at 2, 6, and $24 \mathrm{~h}$ after the meal are presented in Fig. 1. Because the diets were isolipidic, no significant differences were observed for plasma free fatty acids and triglyceride levels between fish fed with or without carbohydrate. Hyperglycemia (up to $16.5 \mathrm{mmol} / \mathrm{l}$ ) was observed in fish fed with carbohydrates 2 and $6 \mathrm{~h}$ after feeding (Fig. 1A). Metformin intake during the 3 days before sampling prevented the observed increase in plasma glucose level 2 and $6 \mathrm{~h}$ after the meal (Fig. $1 A$ ) and in plasma free fatty acids $6 \mathrm{~h}$ after the meal (Fig. 1B) compared with fish fed the + Cho diet.

Our data clearly demonstrate elevated levels of hepatic and muscle glycogen content in fish fed with carbohydrate compared with those fed without carbohydrate (3- and 10-fold higher levels in muscle and liver, respectively) (Fig. 2, $A$ and $B)$. However, dietary metformin had no specific effect on glycogen content (Fig. 2, $A$ and $B$ ). The changes in hepatic glycogen were correlated with the hepatosomatic index ( 3 and $0.7 \%$ in fish with or without carbohydrate, respectively).

Estimates of mRNA levels for enzymes involved in intermediary metabolism. Data on gene mRNA levels for enzymes involved in glucose transport (GLUT4), glycolysis (HK and $\mathrm{PK}$ ), and oxidative metabolism (HOAD and CS) in the muscle of fish fed with and without carbohydrate 6 and $24 \mathrm{~h}$ after the last feeding are reported in Table 3. Regardless of the experimental conditions (with or without carbohydrate), no changes in relative transcript levels were noted for these genes in white muscle $(P>0.05)$. There was also no variation of mRNA levels linked to the metformin intake for these candidate proteins (Table 4).

Regarding regulation of mRNA levels for enzymes of hepatic intermediary metabolism (glycolysis, gluconeogenesis, lipogenesis) (Table 5), carbohydrate intake was associated with a large induction of the GCK mRNA level (on-off regulation) and unexpectedly a two- and fourfold inhibition of PK mRNA levels 6 and $24 \mathrm{~h}$ after the last feeding, respectively (Table 5). 

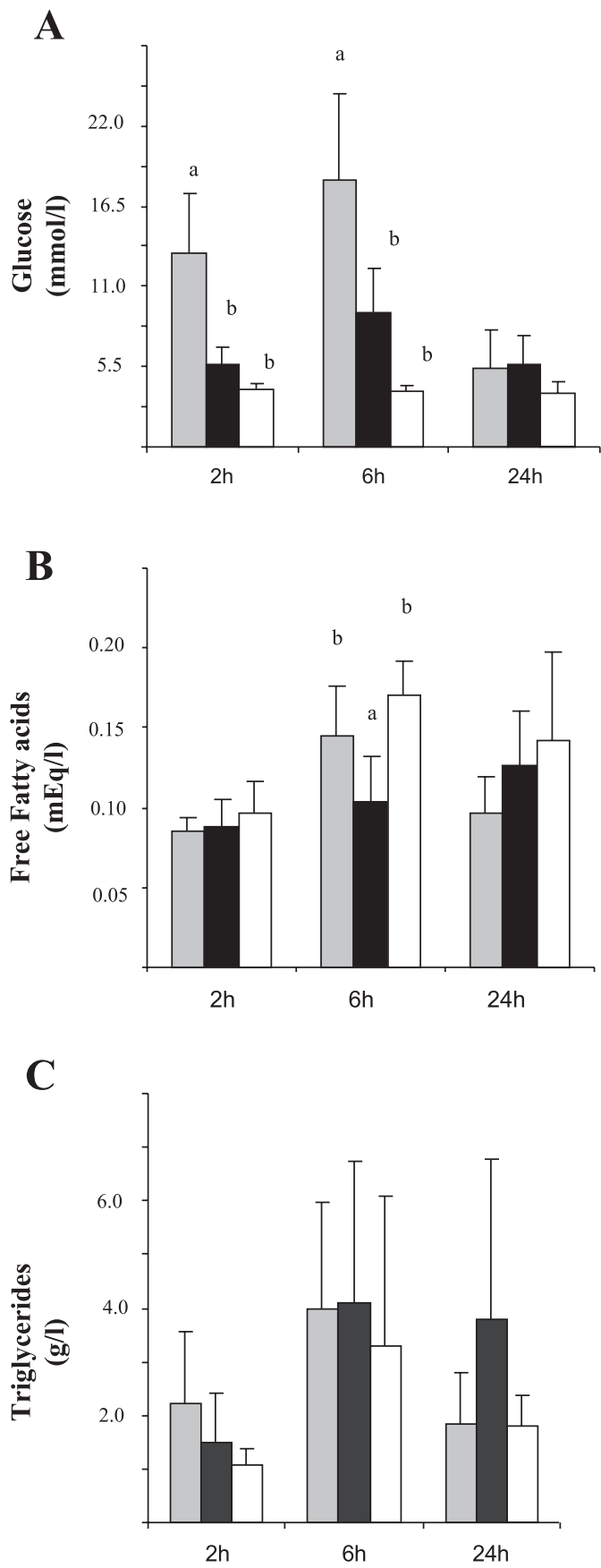

Fig. 1. Postprandial $(2,6$, and $24 \mathrm{~h}$ after meal) plasma metabolites in fish fed with 30\% carbohydrates (gray bar), 30\% carbohydrates + metformin (black bar), or without carbohydrates (white bar). Fish were fed with or without carbohydrates for 10 days followed by metformin for an additional 3 days. $A$ : glucose. $B$ : free fatty acids. $C$ : triglycerides. Values represent means $+\mathrm{SD}$ ( $n=6$ experiments). Mean values for a selected group not sharing a common letter differ $(P<0.05$; Kruskal-Wallis nonparametric test).

For the gluconeogenic pathway, G-6-Pase 1 and 2 mRNA levels were not affected by dietary carbohydrate, whereas a large significant inhibition by dietary carbohydrate of FBPase (8- to 7-fold) and mPEPCK (4- to 2-fold) mRNA levels was observed 6 and $24 \mathrm{~h}$ after the last feeding (Table 5). Among the lipogenic enzymes, FAS mRNA level was unaffected, but G-6-PDH mRNA level was induced by twofold in the carbohydrate-rich diet group (Table 5).
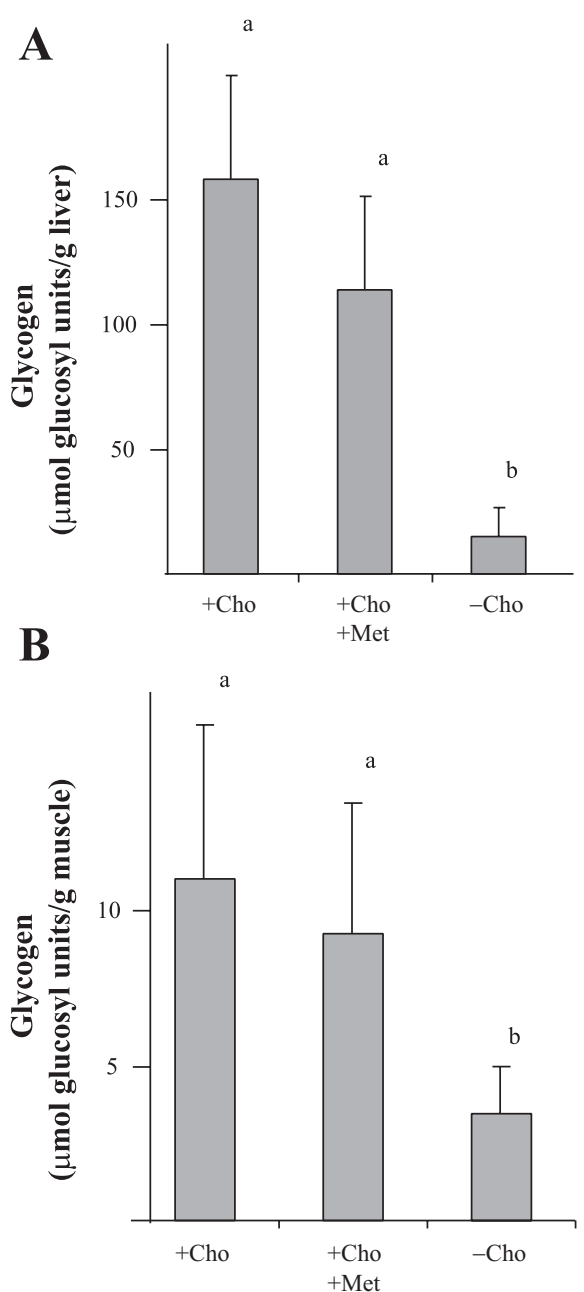

Fig. 2. Glycogen content ( $\mu \mathrm{mol}$ glucosyl units/g tissue) $6 \mathrm{~h}$ after feeding in liver $(A)$ and white muscle $(B)$ of trout. Values represent means $+\mathrm{SD}(n=6)$. Mean values for a selected diet treatment $(+$ Cho: with carbohydrate; + Cho + Met: with carbohydrate and metformin; -Cho: without carbohydrate) not sharing a common letter differ $(P<0.05$; Kruskal-Wallis nonparametric test).

Specific metformin effects on hepatic enzyme mRNA levels are reported in Table 6. Metformin intake did not affect mRNA levels for the two glycolytic enzymes GCK and PK or the last enzyme of glucose production, G-6-Pase (isoforms 1 and 2).

Table 3. Effect of dietary carbohydrates on gene expression in muscle 6 and 24 h after last feeding (compared with fish fed without carbohydrate)

\begin{tabular}{lcccc}
\hline \hline Genes & $\begin{array}{c}\text { 6 h After Feeding } \\
\text { (degree of change) }\end{array}$ & $P$ Values & $\begin{array}{c}\text { 24 h After Feeding } \\
\text { (degree of change) }\end{array}$ & $P$ Values \\
\hline GLUT4 & +1.1 & 0.84 & 1 & 0.82 \\
HK & -1.1 & 0.82 & 1 & 0.71 \\
PK-M & -1.1 & 0.87 & -1.3 & 0.20 \\
HOAD & 1 & 0.98 & +1.2 & 0.43 \\
CS & 1 & 0.97 & 1 & 0.87 \\
\hline
\end{tabular}

Statistical differences in gene expression were evaluated between group means ( $n=6$ samples/group) by randomization tests using REST software (46): + and - signs mean that the target gene is expressed at a lower or higher level, respectively, with respect to the control gene efl $\alpha$. No significant differences were observed $(P>0.05)$. 
Table 4. Effect of metformin on gene expression in muscle 6 and $24 \mathrm{~h}$ after last feeding (compared with fish fed with carbohydrates only)

\begin{tabular}{lcccc}
\hline \hline Genes & $\begin{array}{c}\text { 6 h After Feeding } \\
\text { (degree of change) }\end{array}$ & $P$ Values & $\begin{array}{c}\text { 24 h After Feeding } \\
\text { (degree of change) }\end{array}$ & $P$ Values \\
\hline GLUT4 & -1.4 & 0.22 & +1.2 & 0.55 \\
HK & -1.1 & 0.91 & +1.4 & 0.08 \\
PK-M & +1.1 & 0.88 & +1.5 & 0.22 \\
HOAD & +1.1 & 0.78 & 1 & 0.89 \\
CS & 1 & 0.79 & +1.1 & 0.75 \\
\hline
\end{tabular}

Statistical differences in gene expression were evaluated between group means ( $n=6$ samples/group) by randomization tests using REST software (46). No significant differences were observed $(P>0.05)$.

However, mRNA levels of the gluconeogenic enzymes FBPase and mPEPCK (up to 4- and 2-fold for FBPase and mPEPCK, respectively) and lipogenic enzyme FAS (9-fold) were induced in metformin-fed trout. A weaker but significant increase (1.8-fold) was also observed $6 \mathrm{~h}$ after feeding for G-6-PDH mRNA levels, known to produce NADPH necessary for lipogenesis in fish.

Activities of enzymes involved in intermediary metabolism. Activities for HK and PK were assessed (Fig. 3), HK because of its well-known weak activity in rainbow trout muscle and its proposed role as a bottleneck in dietary glucose utilization in this species (55), and PK because of its atypical decreased mRNA levels in trout-fed carbohydrates (this study) and its enhanced activity after metformin treatment in mammals (1). $\mathrm{HK}$ and PK enzymes were measured $6 \mathrm{~h}$ after the last feeding to coincide with the higher level of plasma glucose at this sampling time (Fig. 1A). In white muscle, no changes in $\mathrm{HK}$ and $\mathrm{PK}$ activities were detected based on diet treatments (Fig. $3, A$ and $B$ ). In contrast, hepatic PK activities were reduced in fish fed carbohydrate compared with those fed without carbohydrate $(P=0.03)$ but without any effect of metformin (Fig. 3B).

The activities of the two lipogenic enzymes FAS and G-6PDH were assessed $24 \mathrm{~h}$ after the last feeding, which correspond to the time of molecular activation of these two lipogenic genes (Table 6). Although there was no effect of diet

Table 5. Effect of dietary carbohydrates on gene expression in liver $6 \mathrm{~h}$ and $24 \mathrm{~h}$ after last feeding (compared with fish fed without carbohydrate)

\begin{tabular}{lcccc}
\hline \hline \multicolumn{1}{c}{ Genes } & $\begin{array}{c}\text { 6 h After Feeding } \\
\text { (degree of change) }\end{array}$ & $P$ Values & $\begin{array}{c}\text { 24 h After Feeding } \\
\text { (degree of change) }\end{array}$ & $P$ Values \\
\hline $\begin{array}{l}\text { Glycolysis } \\
\text { GCK }\end{array}$ & $+28,800$ & $0.003^{*}$ & $+1,000$ & $0.001^{*}$ \\
PK-L & -2.2 & $0.005^{*}$ & -4.7 & $0.009^{*}$ \\
Gluconeogenesis & -1.5 & 0.13 & & \\
G-6-Pase-1 & +1.5 & 0.09 & +2 & 0.085 \\
G-6-Pase-2 & -8.2 & $0.002^{*}$ & -6.8 & $0.003^{*}$ \\
FBPase & -3.7 & $0.008^{*}$ & -2.4 & $0.023^{*}$ \\
mPEPCK & +1.9 & $0.006^{*}$ & +1.9 & $0.023^{*}$ \\
Lipogenesis & +2.6 & 0.177 & -1.3 & 0.621 \\
G-6-PDH & & & & \\
FAS & & & & \\
\hline
\end{tabular}

Statistical differences in gene expression were evaluated between group means ( $n=6$ samples/group) by randomization tests using REST software (46). *Significant difference, $P<0.05$.
Table 6. Effect of metformin in liver on gene expression $6 h$ and 24 h after last feeding (compared with fish fed with carbohydrates only)

\begin{tabular}{lcccc}
\hline \hline \multicolumn{1}{c}{ Genes } & $\begin{array}{c}\text { 6 h After Feeding } \\
\text { (degree of change) }\end{array}$ & $P$ Values & $\begin{array}{c}\text { 24 h After Feeding } \\
\text { (degree of change) }\end{array}$ & $P$ Values \\
\hline Glycolysis & & & & \\
GCK & +1.5 & 0.255 & -1.2 & 0.814 \\
PK-L & +1.2 & 0.468 & +1.7 & 0.178 \\
Gluconeogenesis & & & & \\
G-6-Pase-1 & +1 & 0.999 & -1.3 & 0.426 \\
G-6-Pase-2 & +1.6 & $0.037^{*}$ & +1.2 & 0.452 \\
FBPase & +4.2 & $0.001^{*}$ & +3.4 & $0.012^{*}$ \\
mPEPCK & +2.3 & $0.004^{*}$ & +1.2 & 0.536 \\
Lipogenesis & & & & \\
G-6-PDH & +1.8 & $0.049^{*}$ & +2.9 & $0.043^{*}$ \\
FAS & +1.1 & 0.859 & +9.3 & $0.022^{*}$ \\
\hline
\end{tabular}

Statistical differences in gene expression were evaluated between group means ( $n=6$ samples/group) by randomization tests using REST software (46). * Significant difference, $P<0.05$.

treatment on hepatic FAS activities (Fig. 4B), hepatic G-6$\mathrm{PDH}$ activities increased with $(+\mathrm{Cho}+\mathrm{Met})>(+\mathrm{Cho})>$ (-Cho) (Fig. 4C).

\section{DISCUSSION}

This study used the anti-diabetic drug, metformin, known to play a key role in downregulation of hyperglycemia in mammals to determine if it would improve glucose homeostasis in rainbow trout after dietary carbohydrate intake. Because metformin acts mainly at the molecular level, we analyzed mRNA levels of key metabolic actors in two targets tissues (liver and muscle) known to play important roles in the control of postprandial glycemia.

Effect of a very high level of dietary carbohydrates on $m R N A$ levels in muscle and liver. The ingestion of dietary carbohydrate induced a dramatic but transient (at 2 and $6 \mathrm{~h}$ after feeding only) hyperglycemia (up to $16.5 \mathrm{mmol} / \mathrm{l}$ ) in the rainbow trout consistent with the large body of evidence on the absence of a strict control over glycemia in glucose-challenged rainbow trout $(21,38,55)$. The absence of changes in mRNA levels for GLUT4, HK, PK, HOAD, and CS with high dietary digestible carbohydrate intake confirmed the low capacity of molecular adaptation of white muscle to a high influx of glucose previously observed (21). We, however, found a higher glycogen content in muscle of carbohydrate-fed fish, suggesting enhanced glucose storage in this tissue but presumably insufficient to avoid hyperglycemia, as previously suggested (55).

The response of liver in contrast to the white muscle to high carbohydrate intake was more dramatic but somewhat surprising. Indeed, a huge induction of GCK mRNA level, a more modest induction of G-6-PDH, but also the absence of regulation of G-6-Pase and FAS were detected, confirming previous trends described in trout $(5,38,39)$. However, the reduced mRNA levels of glycolytic PK (confirmed by the enzymatic activities) and gluconeogenic mPEPCK/FBPase noted for the first time in rainbow trout after carbohydrate intake are in contrast to our previous data $(40,41)$. We have no clear explanation for these conflicting results, but we suspect that the very high levels of carbohydrates used in this study $(30 \%)$ associated with the very high postprandial glycemia level (16.5 
Fig. 3. Glycolytic enzyme activities in trout $6 \mathrm{~h}$ after the last meal. $A$ : hexokinase (HK) in the white muscle. $B$ : pyruvate kinase $(\mathrm{PK})$ in white muscle and liver. Values represent means + SD $(n=6)$. Mean values for a selected dietary treatment not sharing a common letter differ $(P<0.05$; Kruskal-Wallis nonparametric test). Enzyme activity units $\mathrm{IU}$, defined as $\mu \mathrm{mol}$ of substrate converted to product, per $\mathrm{min}$, at assay temperature, were expressed/g tissue.
$\mathbf{A}$

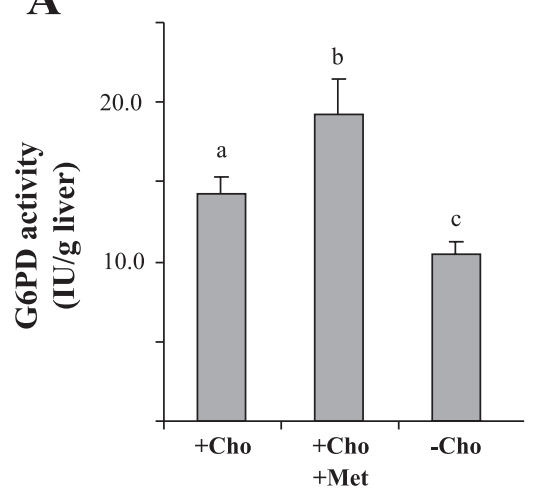

B

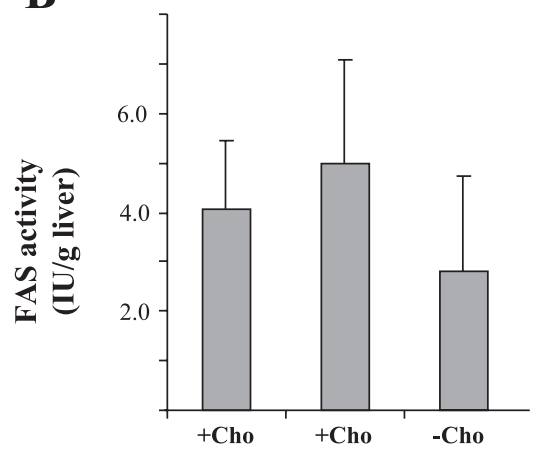

A

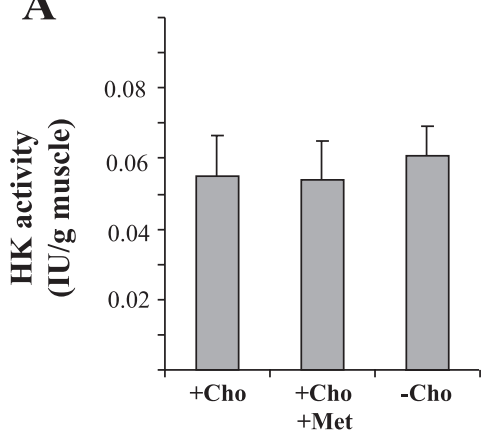

B
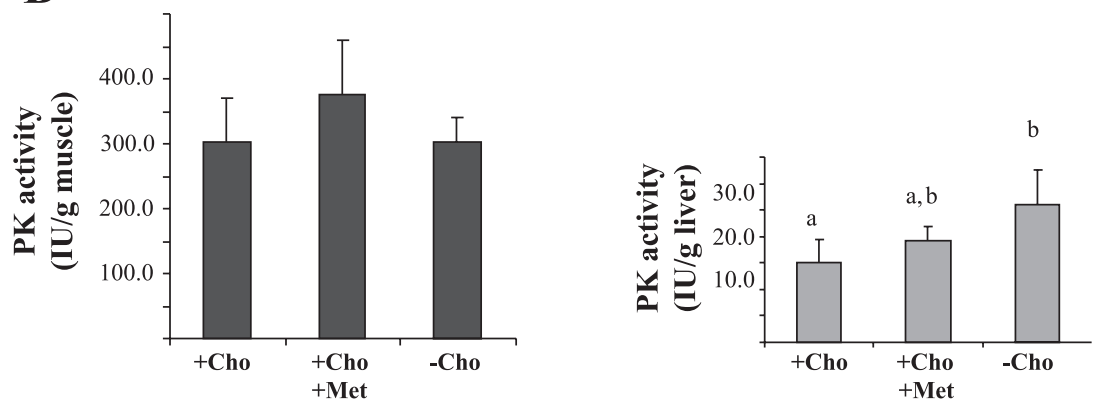

$\mathrm{mmol} / \mathrm{l})$ as well as the relatively short study period (13 days) may be responsible for these conflicting responses. We cannot exclude also a potential effect of the relatively low level of dietary protein (42 vs. $61 \%$; see Table 1) in these diets on these genes especially for the regulation of gluconeogenesis, as previously suggested (25).

Further studies are needed to better understand the atypical molecular regulation of some enzymes by dietary carbohydrate in rainbow trout. Indeed, the inhibition of PK mRNA level (last enzyme of the glycolytic pathway), the absence of inhibition of G-6-Pase mRNA level (last enzyme of the hepatic glucose production), and the absence of induction of the FAS mRNA level (a key lipogenic enzyme) are in contrast to data from mammalian studies $(11,33,52)$. Overall, these observations could have important consequences to explain the low dietary glucose use by the trout liver.

Effect of metformin on mRNA levels in muscle and liver of fish-fed carbohydrates. Metformin is a common human antidiabetic drug used to control glycemic levels in the face of hyperglycemia. The hypoglycemic role of metformin in carbohydrate-fed rainbow trout as reported here is the first-ever report of such a strong effect. Our data are consistent with a decrease in lypolysis or a higher fatty acid uptake in fish fed with metformin as reflected by the lower level of plasma free fatty acids $6 \mathrm{~h}$ after feeding. Overall, the changes in postprandial profiles of these circulating metabolites (glucose, free fatty acids) in trout treated with metformin are in accordance with the data obtained in mammals $(28,44)$; it has been proposed that the hypoglycemic effect of metformin in mammals could be (at least partially) due to the lower intracellular availability of fatty acids (through the inhibition of lypolysis), lower fatty acid oxidation, and consequently a better use of glucose as an energy source.

Metformin has a major impact on regulating glycemia by acting at the molecular level in target tissues (e.g., liver and muscle), specifically suppressing hepatic gluconeogenesis but
Fig. 4. Lipogenic enzyme activities in the trout liver $24 \mathrm{~h}$ after the last meal A: glucose-6-phosphate dehydrogenase (G-6-PDH). B: fatty acid synthase (FAS). Values represent means $+\mathrm{SD}(n=6)$. Mean values for a selected dietary treatment not sharing a common letter differ $(P<0.05$; Kruskal-Wallis nonparametric test). Enzyme activity units IU, defined as $\mu$ mol of substrate converted to product, per min, at assay temperature, were expressed/g tissue. 
also affecting other areas, including energy/lipid metabolism and glucose transport (28). Looking for potential causative factors to explain the hypoglycemic effects of metformin in rainbow trout, the following points are worth considering. First, the hypoglycaemic effect of metformin was not due to a global enhanced efficiency or capacity to store glycogen in liver and muscle (28). Second, we found no higher mRNA levels of the actors playing key roles in glucose transport in muscle (GLUT4) or in muscle and liver glycolysis (HK and PK) to explain a better glucose catabolism linked to the metformin intake $(28,29)$. Third, no changed mRNA levels for at least one key enzyme involved in mitochondrial lipid $\beta$-oxidation (HOAD) were detected to suggest a better use of glucose as an energy source in metformin-treated fish $(3,28$, 44). Finally, an increased level of hepatic gluconeogenic enzyme mRNA for FBPase and PEPCK was found in contrast to mammals $(28,44,53)$. Indeed, this latter point is intriguing, since molecular inhibition of gluconeogenesis, through activation of the kinases, LKB1 and AMPK in liver $(18,53)$, is the main effect of metformin in mammals leading to the hypoglycemic action of this drug. The downregulation of gluconeogenesis by metformin was observed in two other fish species, the zebrafish and common carp, species generally recognized as more glucose tolerant than trout. In these two species, an inhibition of PEPCK mRNA level and glucose production from $\left[{ }^{14} \mathrm{C}\right]$ alanine, respectively, was demonstrated after metformin treatment $(13,22)$. These reports suggest that the absence of the common downregulation of gluconeogenic gene transcription by metformin is specific to the rainbow trout species, possibly linked to its poor capacity to use a high level of glucose.

In contrast to the previous data, which cannot explain the hypoglycemic effect of metformin in rainbow trout, we did observe that metformin intake was associated with higher mRNA levels for two key enzymes involved in hepatic lipogenesis in fish (5), G-6-PDH [the major NADPH producer for lipogenesis in fish liver (5)] and FAS. These molecular data were confirmed at the enzyme level for G-6-PDH but not for FAS; for the latter, this could be due either to posttranscriptional regulations or to the latter postprandial induction of the gene transcription, since no differences were detected $6 \mathrm{~h}$ after feeding, only at $24 \mathrm{~h}$ after feeding. Thus our data support a higher potential of lipogenesis in trout liver that may improve glucose biotransformation to fatty acids, a process thought not to be very efficient in rainbow trout (5). We cannot exclude the possibility that G-6-PDH as a key actor within the pentose phosphate pathways could be directly involved in glucose utilization and transformation of pentoses. Moreover, it is interesting to note that the putative metformin-linked increase of lipogenesis in trout is in contrast with mammalian studies for which there was inhibition of lipogenesis after metformin intake linked to AMPK activation $(18,28)$.

Overall, metformin appears to upregulate the mRNA level of enzymes linked to the gluconeogenic and lipogenic metabolic pathways, suggesting the existence of specific metabolic regulation in the liver of carnivorous animals. In particular, the induction of the hepatic lipogenic pathway could be the major mechanism to better use dietary glucose in rainbow trout. Further studies are necessary to analyze more precisely the mechanisms of action of metformin in rainbow trout, including the analysis of AMPK enzyme (an energy/nutrient sensor) known to be a key mediator of metformin action $(18,53)$.

\section{Perspectives and Significance}

This study provides original data related to the control of glycemia in carnivorous fish fed with carbohydrate. Contrary to our hypothesis regarding the importance of hepatic gluconeogenesis in glucose homeostasis, our study using high digestible carbohydrate diets and metformin indicates that hepatic lipogenesis could be an efficient metabolic pathway to transform glucose (in excess) to lipids (fatty acids) and thus to limit postprandial hyperglycemia. This could be very important because, in contrast to glucose, the utilisation of lipids as a source of energy in fish is considered very efficient, especially during swimming (32). Finally, this study supports the existence of specific regulation of intermediary metabolism in trout, as reflected by the inhibition of PK mRNA level by carbohydrates and the induction of gluconeogenic and lipogenic enzymes by metformin, which could be related to the carnivorous habits of the species. Certainly, the use of metformin as a drug to modulate hyperglycemia during a carbohydrate diet in this carnivorous species needs to be further examined, especially as it relates to lipogenesis. In addition, research in rainbow trout regarding the main transcription factors regulating lipogenesis, including the sterol regulatory element-binding protein 1 (SREBP1) and carbohydrate-response element-binding protein (ChREBP) could further our understanding of the glucose-intolerance of this species.

\section{ACKNOWLEDGMENTS}

We acknowledge M. J. Borthaire, J. Brèque, B. Malgrange, and T. Carbillet for excellent technical assistance. We thank F. Vallee, F. Terrier, Y. Hontang, and F. Sandres for the production of the diets at the Institut National de la Recherche Agronomique experimental farm (Donzacq).

\section{GRANTS}

The European Commission provided a fellowship to M. Lansard ("Sustainable Aquafeeds to Maximise the Health Benefits of Farmed Fish for Consumers"; AQUAMAX No. 016249-2). This work was financed by a France-Canada Research Fund (FFCR 2008, "Improvement of dietary carbohydrate use in carnivorous rainbow trout by using metformin - better diets mean sustainable aquaculture") to S. Panserat and T. W. Moon.

\section{REFERENCES}

1. Argaud D, Roth H, Wiersnsperger N, Leverve X. Metformin decreases gluconeogenesis by enhancing pyruvate kinase flux in isolated rat hepatocytes. Eur J Biochem 213: 1341-1348, 1993.

2. Banos N, Baro J, Castejon C, Navarro I, Gutierrez J. Influence of high-carbohydrate enriched diets on plasma insulin levels and insulin and IGF-I receptors in trout. Regul Pept 77: 55-62, 1998.

3. Bartlett Eaton S K. Mitochondrial beta-oxidation. Eur J Biochem 271: 462-469, 2004.

4. Bergot F. Effects of dietary carbohydrates and of their mode of distribution on glycaemia in rainbow trout (Salmo gairdneri Richardson). Comp Biochem Physiol 64A: 543-547, 1979.

5. Brauge C, Corraze G, Medale F. Effects of dietary levels of carbohydrate and lipid on glucose oxidation and lipogenesis from glucose in rainbow trout $(O$. mykiss) reared in freshwater or in seawater. Comp Biochem Physiol 111A: 117-124, 1995.

6. Capilla E, Diaz M, Gutierrez J, Planas JV. Physiological regulation of the expression of a GLUT4 homolog in fish skeletal muscle. Am J Physiol Endocrinol Metab 283: E44-E49, 2002.

7. Cowey C, Walton M. Intermediary metabolism. In: Intermediary Metabolism. New York, NY: Academic, 1989, p. 259-329. 
8. del sol Novoa M, Capilla E, Rojas P, Baro J, Gutierrez J, Navarro I. Glucagon and insulin response to dietary carbohydrate in rainbow trout (Oncorhynchus mykiss). Gen Comp Endocrinol 139: 48-54, 2004.

9. Diaz M, Antonescu CN, Capilla E, Klip A, Planas JV. Fish glucose transporter (GLUT)-4 differs from rat GLUT4 in its traffic characteristics but can translocate to the cell surface in response to insulin in skeletal muscle cells. Endocrinology 148: 5248-5257, 2007.

10. Diaz M, Capilla E, Planas JV. Physiological regulation of glucose transporter (GLUT4) protein content in brown trout (Salmo trutta) skeletal muscle. J Exp Biol 210: 2346-2351, 2007.

11. Doiron B, Cuif M, Kahn A, Diaz-Guerra M. Respective roles of glucose, fructose, and insulin in the regulation of the liver-specific pyruvate kinase gene promoter. J Biol Chem 269: 10213-10216, 1994.

12. El-Maghrabi M, Lange A, Kummel L, Pilkis S. The rat fructose-1,6bisphosphatase gene. Structure and regulation of expression. J Biol Chem 266: 2115-2120, 1991.

13. Elo B, Villano CM, Govorki D, White LA. Larval zebrafish as a model for glucose metabolism: expression of phosphoenolpyruvate carboxykinase as a marker for exposure to anti-diabetic compounds. $J$ Mol Endocrinol 38: 433-440, 2007.

14. Enes P, Panserat S, Kaushik S, Oliva-Teles A. Effect of normal and waxy maize starch on growth, food utilization and hepatic glucose metabolism in European sea bass (Dicentrarchus labrax) juveniles. Comp Biochem Physiol 143A: 89-96, 2006.

15. Enes P, Panserat S, Kaushik S, Oliva-Teles A. Growth performance and metabolic utilization of diets with native and waxy maize starch by gilthead sea bream (Sparus aurata) juveniles. Aquaculture 274: 101-108, 2008.

16. Fideu MD, Soler G, Ruiz-Amil M. Nutritional regulation of glycolysis in rainbow trout (Salmo gairdneri R.). Comp Biochem Physiol 74B: 795799, 1983.

17. Furuichi M, Yone Y. Change of blood sugar and plasma insulin levels of fishes in glucose tolerance test. Bull Jpn Soc Sci Fish 47: 761-764, 1981.

18. Gaochao Zhou Myers R, Li Y, Chen Y, Shen X, Fenyk-Melody J, Wu M, Ventre J, Doebber T, Fujii N, Musi N, Hirshman MF, Goodyear LJ, Moller DE. Role of AMP-activated protein kinase in mechanism of metformin action. J Clin Invest 108: 1167-1174, 2001.

19. Gutierrez J, Asgard T, Fabbri E, Plisetskaya EM. Insulin-receptor binding in skeletal-muscle of trout. Fish Physiol Biochem 9: 351-360, 1991.

20. Heishi M, Ichihara J, Teramoto R, Itakura Y, Hayashi K, Ishikawa H, Gomi H, Sakai J, Kanaoka M, Taiji M, Kimura T. Global gene expression analysis in liver of obese diabetic $\mathrm{db} / \mathrm{db}$ mice treated with metformin. Diabetologia 49: 1647-55, 2006.

21. Hemre GI, Mommsen TP, Krogdahl A. Carbohydrates in fish nutrition: effects on growth, glucose metabolism and hepatic enzymes. Aquacul Nutr 8: 175-194, 2002.

22. Hertz Y, Epstein N, Zbraham M, Madar Z, Hepher B, Gertler A. Effects of metformin on plasma insulin, glucose metabolism and protein synthesis in the common carp (Cyprinus carpio). Aquaculture 80: 175187, 1989.

23. Kam JC, Milligan CL. Fuel use during glycogenesis in rainbow trout (Oncorhynchus mykiss Walbaum) white muscle studied in vitro. $J$ Exp Biol 209: 871-880, 2006.

24. Kirchner S, Kaushik S, Panserat S. Effect of partial substitution of dietary protein by a single gluconeogenic dispensable amino acid on hepatic glucose metabolism in rainbow trout (Oncorhynchus mykiss). Comp Biochem Physiol 134A: 337-347, 2003.

25. Kirchner S, Kaushik S, Panserat S. Low level of dietary protein is associated with reduced hepatic gluconeogenic enzyme expression in rainbow trout. $J$ Nutr 133: 2561-2564, 2003.

26. Kirchner S, Seixas P, Kaushik S, Panserat S. Effects of low protein intake on extra-hepatic gluconeogenic enzyme expression and peripheral glucose phosphorylation in rainbow trout (Oncorhynchus mykiss). Comp Biochem Physiol 140B: 333-340, 2005.

27. Kirchner S, Panserat S, Lim P, Kaushik S, Ferraris R. The role of hepatic, renal, and intestinal gluconeogenic enzymes in glucose homeostasis of juvenile rainbow trout. J Comp Physiol B 178: 429-438, 2008.

28. Kirpichnikov D, Farlane SI, Sowers JR. Metformin: an update. Ann Intern Med. 137: 25-33, 2002.

29. Klip A, Guma A, Ramla T, Bilan PJ, Lam L, Leiter LA. Stimulation of hexose transport by metformin in L6 muscle cells. Endocrinology 130: 2535-3544, 1992.
30. Krasnov A, Teerijoki H, Molsa H. Rainbow trout (Oncorhynchus mykiss) hepatic glucose transporter. Biochim Biophys Acta 1520: 174178, 2001.

31. Legate NJ, Bonen A, Moon TW. Glucose tolerance and peripheral glucose utilization in rainbow trout (Oncorhynchus mykiss), American eel (Anguilla rostrata), and black bullhead catfish (Ameiurus melas). Gen Comp Endocrinol 122: 48-59, 2001.

32. Magnoni L, Weber JM. Endurance swimming activates trout lipoprotein lipase: plasma lipids as a fuel for muscle. J Exp Biol 210: 4016-4023, 2007.

33. Massillon D, Barzilai N, Chen W, Hu M, Rossetti L. Glucose regulates in vivo glucose-6-phosphatase gene expression in the liver of diabetic rats. J Biol Chem 271: 9871-9874, 1996.

34. Moon TW. Glucose intolerance in teleost fish: fact or fiction? Comp Biochem Physiol 129B: 243-249, 2001.

35. Navarro I, Leibush B, Moon TW, Plisetskaya EM, Banos N, Mendez E, Planas JV, Gutierrez J. Insulin, insulin-like growth factor-I (IGF-I) and glucagon: the evolution of their receptors. Comp Biochem Physiol 122B: $137-153,1999$.

36. Olsvik P, Lie K, Jordal A, Nilsen T, Hordvik I. Evaluation of potential reference genes in real time RT-PCR studies of Atlantic salmon. BMC Mol Biol 17: 6-21, 2005.

37. Palmer TN, Ryman BE. Studies on oral glucose intolerance in fish. $J$ Fish Biol 4: 311-319, 1972.

38. Panserat S, Medale F, Blin C, Breque J, Vachot C, Plagnes-Juan E, Gomes E, Krishnamoorthy R, Kaushik S. Hepatic glucokinase is induced by dietary carbohydrates in rainbow trout, gilthead seabream, and common carp. Am J Physiol Regul Integr Comp Physiol 278: R1164R1170, 2000.

39. Panserat S, Medale F, Breque J, Plagnes-Juan E, Kaushik S. Lack of significant long-term effect of dietary carbohydrates on hepatic glucose6-phosphatase expression in rainbow trout (Oncorhynchus mykiss). J Nutr Biochem 11: 22-29, 2000b.

40. Panserat S, Plagnes-Juan E, Breque J, Kaushik S. Hepatic phosphoenolpyruvate carboxykinase gene expression is not repressed by dietary carbohydrates in rainbow trout (Oncorhynchus mykiss). J Exp Biol 204: 359-365, 2001.

41. Panserat S, Plagnes-Juan E, Kaushik S. Nutritional regulation and tissue specificity of gene expression for proteins involved in hepatic glucose metabolism in rainbow trout (Oncorhynchus mykiss). J Exp Biol 204: 2351-2360, 2001.

42. Parrizas M, Banos N, Baro J, Planas J, Gutierrez J. Up-regulation of insulin binding in fish skeletal muscle by high insulin levels. Regul Pept 53: 211-222, 1994.

43. Parrizas M, Planas J, Plisetskaya EM, Gutierrez J. Insulin binding and receptor tyrosine kinase activity in skeletal muscle of carnivorous and omnivorous fish. Am J Physiol Regul Integr Comp Physiol 266: R1944R1950, 1994.

44. Perriollo G, Misericordia P, Volpi E, Santucci A, Santucci C, Ferrannini E, et al. Acute antuhyperglycemic mechanisms of metformin in NIDDM. Evidence for surppression of lipid oxidation and hepatic glucose production. Diabetes 43: 920-928, 1994.

45. Pfaffl MW. A new mathematical model for relative quantification in real-time RT-PCR. Nucl Acids Res 29: E45-E45, 2001.

46. Pfaffl MW, Horgan GW, Dempfle L. Relative expression software tool (REST@) for group-wise comparison and statistical analysis of relative expression results in real-time PCR. Nucl Acids Res 30: 9-36, 2002.

47. Plagnes-Juan E, Lansard M, Seiliez I, Médale F, Corraze G, Kaushik S, Panserat S, Skiba-Cassy S. Insulin regulates the expression of several metabolism-related genes in the liver, and primary hepatocytes of rainbow trout (Oncorhynchus mykiss). J Exp Biol 211: 2510-2518, 2008.

48. Polakof S, Míguez JM, Moon TW, Soengas JL. Evidence for the presence of a glucosensor in hypothalamus, hindbrain, and Brockmann bodies of rainbow trout. Am J Physiol Regul Integr Comp Physiol 292: R1657-R1666, 2007.

49. Polakof S, Panserat S, Plagnes-Juan E, Soengas JL. Altered dietary carbohydrates significantly affect gene expression of the major glucosensing components in Brockmann bodies and hypothalamus of rainbow trout. Am J Physiol Regul Integr Comp Physiol 295: R1077R1088, 2008.

50. Richard N, Kaushik S, Larroquet L, Panserat S, Corraze G. Replacing dietary fish oil by vegetable oils has little effect on lipogenesis, lipid 
transport, and tissue lipid uptake in rainbow trout (Oncorhynchus mykiss). Br J Nutr 96: 299-309, 2006.

51. Scott DK, O'Doherty RM, Stafford JM, Newgard CB, Granner DK. The repression of hormone-activated PEPCK gene expression by glucose is insulin-independent but requires glucose metabolism. J Biol Chem 273: 24145-24151, 1998.

52. Sul HS, Wang D. Nutritional and hormonal regulation of enzymes in fat synthesis: studies of fatty acid synthase and mitochondrial glycerol-3phosphate acyltransferase gene transcription. Anпu Rev Nutr 18: 331-351, 1998.
53. Shaw RJ, Lamia KA, Vasquez D, Koo SH, Bardeesy N, Depinho RA, Montminy M, Cantley LC. The kinase LKB1 mediates glucose homeostasis in liver and therapeutic effects of metformin. Science 310: 1642-1646, 2005.

54. Thivend P, Mercier C, Guilbot A. Determination of starch with glucoamylase. In: Methods in Carbohydrate Chemistry, edited by R. L. Whistler and J. N. Bemiller. New York, NY: Academic, 1972, vol. VI, p. $100-105$.

55. Wilson RP. Utilization of dietary carbohydrate by fish. Aquaculture 124: 67-80, 1994.

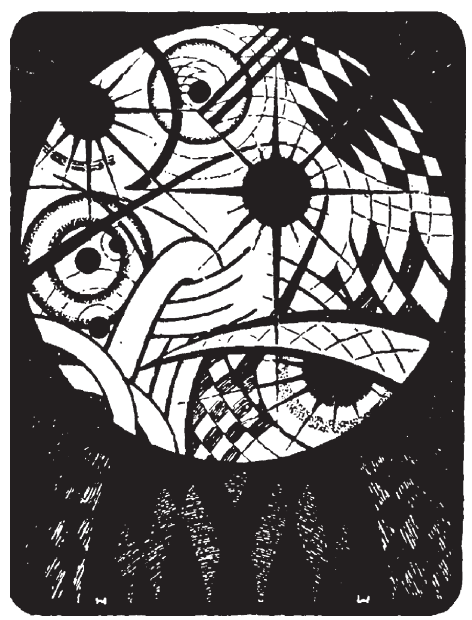

